\title{
Beyond Peak Oil in Post Globalization Civilization Clash
}

\author{
James Leigh $^{*}$
}

\author{
School of Business, University of Nicosia, Nicosia, Cyprus
}

\begin{abstract}
The industrial society for the last century has been stoked by oil as the cheap energy source. However, ominous signs of oil depletion, in fulfillment of M. King Hubbert's "Peak Oil" theory, may be eerily encroaching upon us and may portend "The Olduvai Theory's" dramatic consequences. The implications of dwindling cheap oil supplies are catastrophic for maintaining industrial societies' economic development. Also the anticipated economic development of the less developed countries would be critically threatened without cheap oil. These less developed countries have already set their will towards becoming industrialized, with economic development similar to that of the Western more developed countries. However, the possibility of oil depletion may show there are considerable barriers to thwart the universalization of economic development to the world's less developed as oil prices skyrocket. This may all work together to facilitate civilization clash in frantic efforts for each political bloc to secure the world's oil resources, or at least the reliable supply of oil at the best price. Nations may weld together to forge continent-wide civilization superpowers, for advantage in a looming new worldwide post-oil era, when cheap readily available oil may not be taken for granted. This could prove to be a test of how the newly formed superpowers will cooperate or compete with each other.
\end{abstract}

Keywords: Peak oil, globalization, civilization clash, the Olduvai theory, economic development.

\section{INTRODUCTION}

Ted Trainer [1] predicted large and permanent increases in oil prices after the year 2000 due to increasing scarcity. In fact in March 2008, oil broke through the psychological ceiling of $\$ 100$ a barrel and rose well beyond that on the way to $\$ 120$ a barrel. Even the president of OPEC (Organization of Petroleum Exporting Countries) has warned of oil reaching $\$ 200$ a barrel [2]. Ferris-Lay [3] has forecast that the black liquid gold could eventually climb to an incredible $\$ 300$ a barrel.

This paper attempts to critically integrate the scientific hypotheses of "Peak Oil" [4] and "The Olduvai Theory" [5] into a geopolitical world view in the third millennium based on a civilization clash hypothesis [6]. Specifically, in this paper, we will consider the causes and the context of the apparent increasing scarcity of oil and its rising price, and investigate the implications of this, with the help of the Olduvai theory, in a post-globalization world fragmenting into civilizations, with the threat of civilization clash.

History, current changing world circumstances and the threat of dwindling energy-resource supplies suggest that the oil-fired industrial age is destined to be short lived. The bell curve below shows the levels of historic and prospective oil production over two millennia. This graph, shown in Fig. (1) illustrates the assertion that the life expectancy of Industrial Civilization is around 100 years - from 1930 to 2030 [7, 8].

It has been the plentiful supply of cheap oil (increasingly from less developed countries) that was the main factor, along with the necessary natural resources and skilled manpower, that made the miracle of the industrial era, of about

*Address correspondence to this author at the School of Business, University of Nicosia, Nicosia, Cyprus; E-mail: leigh.j@unic.ac.cy
Oil Production 2000 years

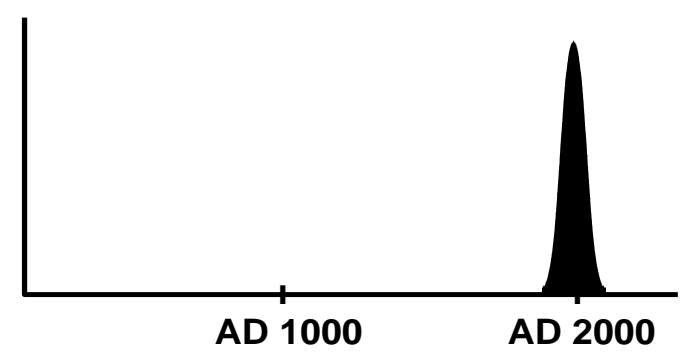

Fig. (1). Oil production over two millennia [8].

100 years, possible in the Western more developed countries, and particularly in Europe and the United States.

However, the plentiful supply of cheap oil has been short lived. Even as predicted by Dr. M. King Hubbert's bell curve method, the peak for oil production in the United States was reached way back in 1970. This "Peak Oil" method began with Hubbert, a Shell Oil geophysicist who determined that when an oil field was half depleted, it had hit peak production and was set for production decline. Not only did he estimate, in 1956, that U.S. oil production would peak around 1970, but also with this method he later predicted the world peak would be between 1995 and 2000 [9].

Several internationally known and respected petroleum experts, Colin Campbell, Jean Laherrere, Brian Fleay, Roger Blanchard, Richard Duncan, Walter Youngquist, and Albert Bartlett (with various methodologies) all estimated a peak in conventional oil would hit around 2005. Further, the CEOs of Agip and ENI SpA, (Italian oil companies) and ARCO (a BP subsidiary since 2000) also published estimates for peak 
oil to be reached in 2005. In November 1997, the International Energy Agency (IEA) convened an Oil Conference in Paris. Among the various papers presented, Jean Laherrere and Colin Campbell presented three empirical papers on oil depletion. As a result of this conference, the IEA prepared a paper for the G8 Energy Ministers' Meeting in Moscow, March 31, 1998. The IEA adopted Laherrere and Campbell's view, and forecast an imminent peak in conventional oil for 2012. This represents a significant reversal of the IEA position from the no-limits stance of previous years [10].

In fact by 2006 not only had most countries reached their peak oil production and its subsequent fall-off in production, but declining world oil production levels may be looming, heralding dwindling oil on world markets and shrinking reserves in the ground. The graph below in Fig. (2) from Bowman shows this state of affairs with world oil production having peaked in early 2006, and from there we see a trend of continual slight decline, and by 2030 oil production is predicted to drop to $40 \mathrm{mbpd}$, less than half today's production [11]. Other analysts (for example most recently Zittel and Schindler) [12] give similar analyses for oil supply dropoff beginning around now. Actually the industry is harboring pent up forces for permanent steeper decline to set in.

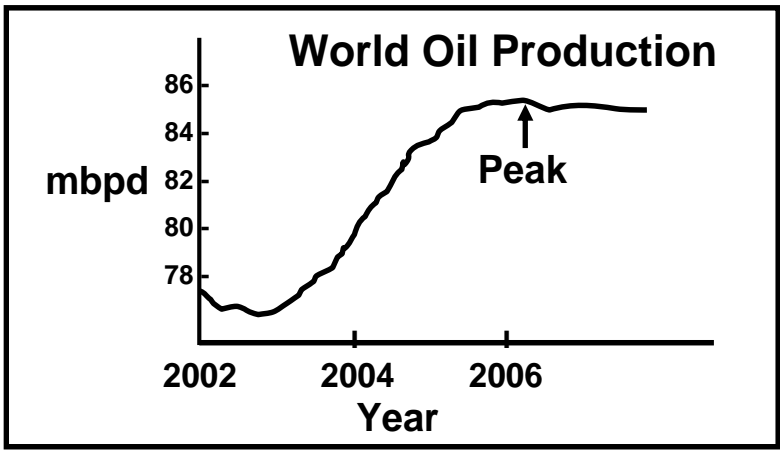

Fig. (2). World oil production peak [11].

In fact world conventional crude oil data [13] show that production levels fell from $73.81 \mathrm{mbpd}$ in 2005 to 73.27 mbpd in 2007, and thus many are commenting that there has actually been a declining plateau since 2005. However, figures have repeaked slightly as production lifted marginally in 2008, with conventional crude oil production around 74.48 mbpd, not quite off the plateau, but a slight, and probably temporary, increase [14].

However, various comments now being heard from high in the oil industry may actually clarify this repeaking. Ali Naimi, the Saudi Oil Minister said, "Limited capacity along the entire supply chain is the real source of current global supply tightness and represents the greatest threat to ensuring adequate energy to fuel future economic growth". Head of Libya's NOC (National Oil Corporation), Shokri Ghanem admitted that "Very little can be done by anyone, there is not enough spare capacity" [15].

Even further, there may not only be a problem of falling availability of oil, but at this critical time, the demand for oil supplies is rapidly escalating. Increasingly rapid economic development in several less developed countries around the world (including China and India) is producing an insatiable demand for oil and other energy resources.
Recently Abdalla Salem El-Badri [16], the Secretary General of OPEC (Organization of Petroleum Exporting Countries) showed that the world demand for energy has had a dramatic fourfold increase since 1960. And forward looking Ramzi Salman [17] says we can expect a high and increasing demand for oil against low spare oil production, and inadequate refining capacities, along with relatively high prices and volatile markets.

In China alone the daily consumption has increased from 3.4 million barrels per day to 6.7 million barrels, a massive increase of approaching $100 \%$ in the years 1995 to 2004 . China alone consumed almost $13 \%$ of the world's total oil production in 2004. Similar trends in oil demand have occurred and are projected for India, although not from the same high base level. Even so China and India together in 2004 consumed a massive amount of about $18 \%$ of the world oil supply. The chart below in Fig. (3) from Stanford [18] shows the historic continuing increase in demand for oil, in China and India, to fire up their impressive economic development.

\section{China \& India Oil Consumption}

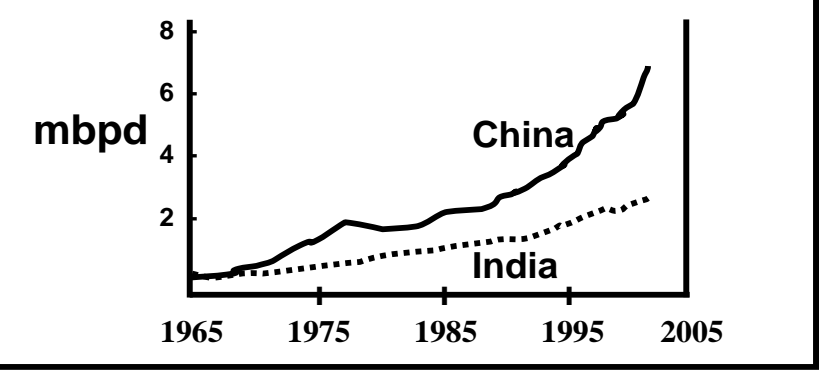

Fig. (3). Escalating China and India oil consumption [18].

It has been estimated that the extra oil supply equivalent to three Saudi Arabias will have to come on tap by 2030 just to keep pace with world demand [19]. It is very hard to see how this massive extra supply will be achieved.

\section{THE UNDERLYING PROBLEM}

Abdalla Salem El-Badri [16] gave an address for the Nicosia Chamber of Commerce. In his address "Oil Outlook and Investment Challenges" he raised some of the problem issues of the international oil sector and pointed out the following:

- Oil is exhaustible

- Development of oil projects is capital intensive with long lead times

- $\quad$ Petroleum projects are facing huge increases in costs

- $\quad$ Energy is crucial for sustainable development

- Many factors affect the supply of oil, some of which are:

- Refinery bottlenecks [due to inadequate refining capacity]

- Geopolitical problems

Actually these are steep problems for the oil sector to surmount, as we possibly approach the global exhaustion point for extractable oil. The necessary investments to boost 
production, to keep pace with demand, have not been made, and he highlights that such investment requires huge sums of money and long lead times. However, as El-Badri points out, energy is crucial for maintaining economic development. The problem is that plentiful supply of cheap oil has been generally dwindling, causing price rises, because of limited crude availability and refineries that are already working at full tilt. Not to mention the serious geopolitical problems unfolding around the world.

The world may be confronting a problem of gigantic magnitude as the global demand for oil escalates at a time when the production levels are sagging. And an incredible 54 of 65 largest oil producing countries in the world have passed their production peak [20].

Even though ascertaining the amount of oil reserves yet remaining is problematic, based on the latest credible figures there are about 1.3 trillion barrels of proven (recoverable) oil reserves worldwide [21]. The math speaks for itself - with present conventional crude oil consumption rates of around 75 mbpd, given the amount of oil reserves, mankind will reach total exhaustion for oil in 45 years (unless more recoverable oil is found in useful quantities). If the rising levels of oil consumption were factored in that would mean the exhaustion point could be reached within 25 years. Of course the dwindling supplies, we may already begin to see, could herald this looming exhaustion point. It is important to note here that economic, political and social conditions will likely worsen to critical levels if oil supplies dwindle, long before we reach oil's end.

However, the level of proven recoverable reserves is problematic. Many OPEC countries have been announcing reserve numbers which are very strange. Either their reported reserves remain the same year after year - suggesting that new discoveries exactly match production, or they have suddenly increased their reported reserves by unfeasibly large amounts. This data is not so odd if we realise that OPEC takes into account a country's reserves when fixing production quotas - the more oil you say you have, the more you're allowed to extract and sell.

Further, oil reserves are often used as collateral for loans - for example, the $\$ 50$ billion loan from the U.S.A. to Mexico in December 1994 when the Mexican Peso fell dramatically. At this time the Mexican Central Bank's international reserves fell from $\$ 29$ billion to $\$ 5$ billion. To stave off further collapse of the Mexican economy, President Clinton signed a $\$ 50$ billion "Emergency Stabilization Package" loan to the Mexican government in January 1995. The collateral for the loan was Mexico's pledge of revenues from its future petroleum exports.

Another problem with compiling data on reserves is that there are very flexible definitions of the different types of oil involved when recording known oil reserves or predicting the amount of oil yet to be discovered. It is important in any reporting, that the amounts of reserves yet to be extracted or discovered, are clearly separated into the different types of oil. Unfortunately, the compilers of reports may not always be so meticulous on this issue. The broad definitions of oil types are:
Conventional oil (around $95 \%$ of all oil to date)

Unconventional oil:

Oil sands

Shale oil

Oil not recoverable with present technology - for example too deep

These distinctions are important, because the global economy has been based on cheap pumpable petroleum which comes exclusively from conventional oil. Oil type has important implications for the required technology, the final cost of the product, and even the likelihood that it will ever be recovered.

No one really knows how much unconventional oil may yet be discovered. However, it will likely fall under one of the following categories: impossible to extract; or due to difficult extraction circumstances, not worth it because of low or negative net energy gain; or not extractable with present technology at today's prices. It is important to note that any future more developed technology needed to extract this "available" oil, is likely to be astronomical in cost by today's standards. It is therefore misleading not to consider these resources completely separate from conventional oil [4]. Finally, while anticipating any such oil as a theoretical possibility for future use is not illogical, it is still indeed a long shot, and somewhat against the odds, and definitely would involve a long lead time. Also it is theoretically feasible that technology will advance to make it possible for this elusive oil to be eventually extracted with an acceptable positive net energy gain - but still, the challenge is considerable. As some may critically argue, there is a limit to technology after all, and we may be on that verge in drilling for oil.

As Kerr and Service [22] argue it is not IF there will be a problem with inadequate oil supply but WHEN. They suggest that there is little disagreement that the world will soon be running short of oil. The debate is over how soon. Global demand for oil has been rising at $1 \%$ or $2 \%$ each year. We are now sucking almost 1000 barrels of oil from the ground every single second, and future percentage rises in the global demand could escalate as attempts are made to universalize economic development.

So can the earth's oil reserves sustain such extraction levels? Even though the estimates of unknown oil reserves are controversial and problematic, there have been no large oil-field finds since the 1960s. And many believe that the declared "known" oil reserves coming out of some countries are actually way overstated [23, 24]. The graph [20] below, in Fig. (4) shows, over 10-year average clusters, the dwindling discovery levels of known reserves has been collapsing over recent decades, and has led us to this very time when present and future demand continues to escalate. (Each decade begins with the year shown, and for example, the average yearly finds for the 1960s is approaching 50 gbpy over a ten year period.) No wonder that the threat of short supply is borne out by a recent general trend of decreasing supply of oil since 2006 in the face of escalating demand [11]. 


\section{Comparison between Reserves \& Demand}

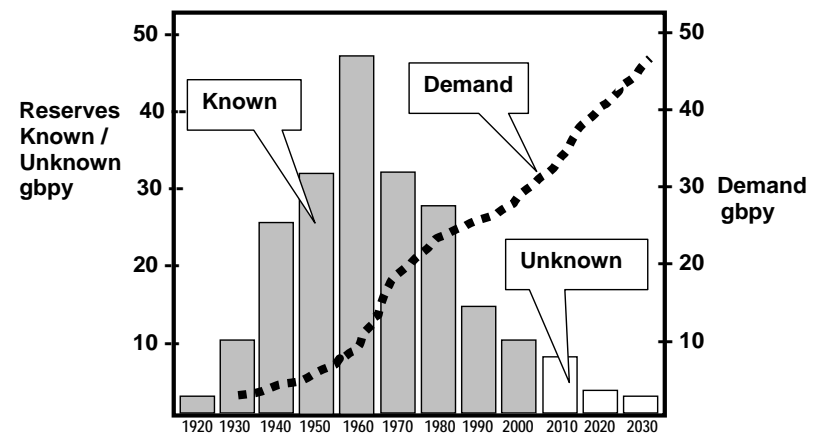

Fig. (4). Comparison between oil reserves and demand [20].

It has been suggested by some that oil fields may tend to naturally replenish over time [25]. However, the process and rate of this self restoration is not clear, under debate, and still very controversial.

Even the remaining best endowed oil countries have reserves that will soon begin to decline to critical levels. It seems that oil may now be largely around the Persian Gulf. In 2006 more than $30 \%$ of the world's extracted oil emanated from the Gulf [26]. It seems the only major oil producers with significant readily extractable reserves of oil left, that will not on average decline in production levels for around another 15 years, are these states of the Persian Gulf:

\section{Abu Dhabi}

Kuwait

Iraq

\section{Saudi Arabia}

The future overall shortfall for world oil supply could be rather daunting. From around now we can see that the threat of dwindling supply of oil may increasingly fail to meet the demand [27-29]. And the graph below, in Fig. (5) suggests increasingly massive oil shortfalls in the next few years.

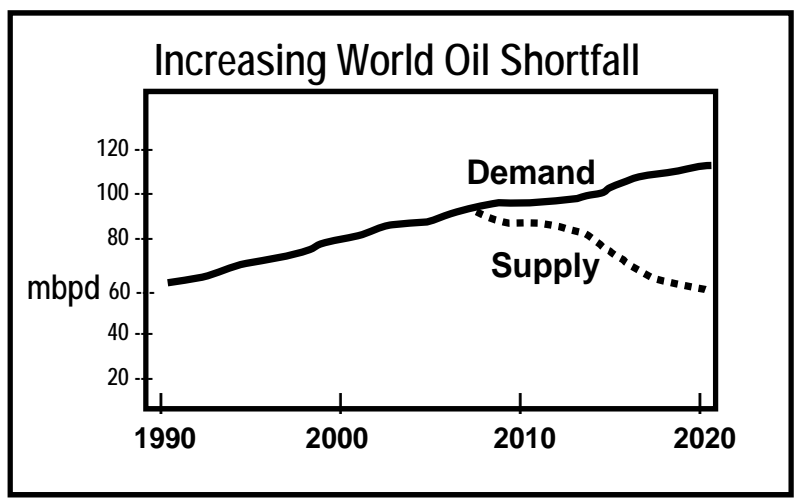

Fig. (5). Increasing world oil shortfall [27-29].

Actually the facts for the future of oil could be:

Declining world production

Increasing world demand

Escalating prices
No guarantee of declared oil reserves, as the levels may be very overstated, or of finding any more significant, as yet unknown, oil fields.

The undersupply of extractable oil may cause a rapid threatening economic decline in the next two or three years, and extractable oil may be largely exhausted within the next twenty years.

As we have already seen, at the present time extraction facilities for producing crude are working at about full capacity, and there is no room for any significant increase in the output levels of refineries either. And even if there was the extra refining capacity, there are not the transport facilities around the world to carry any significant increase in the oil and petrochemical payload. This lack of transport facility could be alleviated in the future when additional facilities come into service, and of course it is possible that refining capacity could be increased. However for both of these there would be a lead time of a decade or so.

This all means that the world could be facing crunch point - and very soon. The eagerly anticipated economic development of the less developed countries may be stymied by lack of adequate cheap oil supplies, and the more developed countries hindered in any future economic development by dwindling and increasingly expensive oil. This could mean there will be no winners in the world for economic development as the West declines and the poorer countries falter and remain less developed.

Duncan $[7,5]$ invoking the Olduvai theory shows that the world energy production per capita has been declining since way back in 1979, and he further argues that by around now a catastrophic energy per capita drop off will set in. He forecasts the dramatic and extremely debilitating effects that will develop as countries fail to produce electricity, and their civilizations' economic development is crippled, and literally collapses back into the dark ages.

The Olduvai Theory hypothesizes that readily available cheap energy is vital for the maintenance of the industrial society and its continued economic development. More specifically, it is argued that oil is most important as a cheap freely available energy source, and without adequate freely available oil, Duncan predicts that we will not have reliable electricity supply, which is essential for our developed societies.

In this context Duncan, in the Olduvai theory, reasons that without oil and its petrochemical products as an energy source, we are not able to use heavy machinery, and ships and transport vehicles. And so without oil and these machines we will not be able to neither extract nor transport coal, gas and uranium, nor the oil itself. And these four energy sources account for over $80 \%$ of world electricity production.

If Olduvai eventually plays out to the full extent, the eventual permanent blackout of electricity will be crippling. Without oil to continue to fire up our industrial society, we will be without: public electricity, transport, industry's processed products (food, clothing, packaging, and machinery), and communication and computer services. A little bit of brainstorming shows that the society and its systems would come eventually to a standstill. A totally paralyzing set of 
circumstances with hunger and deprivation on an unprecedented scale.

Obviously this has huge implication at national and international levels and in world geopolitics. Any nation that begins to see the edge of the Olduvai catastrophe approaching will surely do all it can to avoid such pervasive economic, political and societal decline. It may be that oil scarcity and high prices, along with the Olduvai effect, will be major factors eventually facilitating post-globalization world fragmentation, as civilizational power blocs vie for politicall and economic advantage, pushing the world towards continent-wide civilization superpowers in civilization clash.

\section{NATURE OF THE OIL SHORTFALL PROBLEM}

The exact nature of the problem is that not only may we have dwindling supplies in the face of growing demand leading to escalating prices, but also eventually we will stop extracting oil from the ground altogether if the net energy return is not worth it. For example, when the oil is so deep or difficult to extract, that it takes one barrel of oil to extract say one or two barrels (or even worse), it is obvious that there is no net gain worth the effort. Actually oil becomes unavailable and "exhausted" before there is no oil left - the "exhaustion" point is when it is no longer worth it to spend the energy to get so little back.

However, the following quote highlights that there are no easy oil substitutes:

\begin{abstract}
Alternative energy sources have their problematic issues. Nuclear fission supporters have never found a noncontroversial solution for disposing of long-lived radioactive wastes, and concerns over liability and capital costs are scaring utility companies off. Renewable energy sources are diffuse, making it difficult and expensive to corral enough power from them at cheap prices [22].
\end{abstract}

As an example of the absolute inability of alternative energy to replace the present energy production level of oil, Odum [30] cites the case of solar energy with the fact that "the U.S.A. is presently using fossil fuels more than 100 times greater than the total absorption of solar radiation across the entire USA". Further, calculations show that the production and installation of solar photovoltaic cells consume twice as much energy as they produce. So even if all the energy produced was put back into production, then one could build only half as many cells each generation - obviously solar cell technology is not sustainable. Even if the efficiency of solar cells doubled, all of the energy produced would have to be used to manufacture new cells, which would still bequeath a zero net benefit to society [10]. Actually, even though not generally realised, such failing net energy figures apply to various alternatives to conventional oil. In that sense many energy technologies that we think are sustainable, are not really.

In reality, no other energy source can be comprehensively substituted for cheap readily available oil. Any use of alternative energy fuels can only partly and minimally make up for the possible looming oil supply shortfall. No other transportable and versatile energy resource is as energy dense as oil. Nuclear energy, not only is dangerous because of the possibility of industrial accident or terrorism, but it can only minimally fill the gap for a few short decades, before it is spent, and the unwieldy hazardous waste problem will be left with us for thousands of years. Other alternative fuel technologies have serious shortcomings with one or a combination of the following factors:

Massive environmental degradation or large volumes of waste material on site (oil sands, shale oil, hydroelectric up- and down- stream).

Dangerous waste disposal problem after fuel is spent (nuclear).

In need of much more technological development to be fully viable (solar, wind, wave, tidal, fusion, ocean thermal, hydrogen).

Only for public electricity production (coal, nuclear, geothermal, hydroelectric, wave, tidal, fusion, ocean thermal)

Only appropriate for some few limited sites (oil sands, shale oil, tidal, hydroelectric, geothermal, wind, wave).

Subject to depletion or unsustainable technology (conventional fossil fuels, oil sands, shale oil, nuclear, geothermal declines in effectiveness, hydroelectric silts up, solar has negative net energy).

Terrorism (nuclear material used for construction of nuclear weapons; and the possibility of an attack on reactor sites, or storage or waste storage sites)

Environmental pollutant (all fossil fuels and especially coal).

Low net energy (amount of energy or fuel needed to produce the final amount of energy), or even negative net energy, and therefore affects how expensive the final fuel produced is. Obviously any technology with very low or negative net energy is not sustainable. It may be that some of the alternative fuel technologies, in this vein, are really unsustainable, in spite of popular wisdom (oil sands, liquid coal, shale oil, biomass, solar, hydrogen).

Directly competes with resources for much needed food production. For example, the land is taken from food production, and the plant product itself is not used for food, but to produce ethanol (biomass).

To bring many of the above points together, in the Table 1 below, the various characteristic advantages and disadvantages of energy resources are listed:

The following points [31] help towards a distillation of the current status quo concerning alternative energy and oil production:

Within the lifetime of our industrial civilization extractable oil is dwindling and finite

As the demand for oil exceeds supply some nations may go without

Petroleum products have highest energy density

Critical economic repercussions will accrue from the rising energy prices 
Table 1. Characteristics of Energy Sources

\begin{tabular}{|c|c|c|c|c|c|c|c|}
\hline Fuel & Renew & $\begin{array}{l}\text { Low net } \\
\text { energy }\end{array}$ & $\begin{array}{l}\text { Wastel } \\
\text { danger }\end{array}$ & $\begin{array}{l}\text { Only } \\
\text { public } \\
\text { power }\end{array}$ & Vehicles & $\begin{array}{l}\text { Other } \\
\text { problems }\end{array}$ & $\begin{array}{l}\text { Few } \\
\text { sites }\end{array}$ \\
\hline Oil sands & & $\checkmark$ & $\checkmark w$ & & $\checkmark$ & $\begin{array}{l}\checkmark \text { Degrades } \\
\text { Environment }\end{array}$ & $\checkmark$ \\
\hline Gas & & & & & $\bar{r}$ & $\begin{array}{l}\text { Total energy } \\
\text { reserve less } \\
\text { than coal }\end{array}$ & \\
\hline Coal & & $\checkmark$ Liquid & & $\checkmark$ & $\checkmark$ Liquid & $\checkmark$ Pollutant & \\
\hline Shale oil & & $\bar{r}$ & $\sqrt{ } \mathrm{W}$ & & 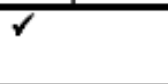 & $\begin{array}{l}\text { Degrades } \\
\text { environment }\end{array}$ & $\bar{\checkmark}$ \\
\hline Nuclear & & & $\checkmark W D$ & $\checkmark$ & & $\sqrt{\text { Terrorism }}$ & \\
\hline Geothermal & $\checkmark$ & & & $\checkmark$ & & $\checkmark$ Decline & $\checkmark$ \\
\hline Biomass & $\sqrt{2}$ & $\sqrt{2}$ & & & $\checkmark$ & $\checkmark$ Food competitor & \\
\hline Hydroelectric & Silts up & & & $\checkmark$ & & $\begin{array}{l}\text { VUp \& down } \\
\text { stream degrades } \\
\text { environment }\end{array}$ & $\checkmark$ \\
\hline Solar & $\bar{v}$ & $\checkmark$ & & & $\sqrt{2}$ & $\sqrt{\text { Batteries }}$ & \\
\hline Wind & $\bar{r}$ & & & & & $\sqrt{\text { Batteries }}$ & $\checkmark$ \\
\hline Wave & $\checkmark$ & & & $\checkmark$ & & $\checkmark$ Development & $\checkmark$ \\
\hline Tidal & $\bar{v}$ & & & $\sqrt{2}$ & & $\checkmark$ Development & $\bar{v}$ \\
\hline Fusion & $\sqrt{ }$ & & & $\bar{r}$ & & $\sqrt{\text { Development }}$ & \\
\hline $\begin{array}{l}\text { Ocean } \\
\text { Thermal }\end{array}$ & $\checkmark$ & & & $\bar{r}$ & & VDevelopment & \\
\hline Hydrogen & $\checkmark$ & $\checkmark$ & & & $\checkmark$ & $\checkmark$ Development & \\
\hline
\end{tabular}

Alternative energy sources have lower net energy and are more expensive per energy unit

Replacing oil based infrastructures has a long lead time, and involves high expenditure and energy consumption

These points in themselves may not be insurmountable problems, but are still a massive challenge for any sizeable transition to alternative fuels. So alternative fuels may be workable to some limited extent, but would require global sacrifice and cooperation on a permanent basis, to a degree that would revolutionize and simplify our lifestyle and so require much less energy. There is nothing to suggest that is possible in the foreseeable future.

However, the world does not, at present, have the oil resources and infrastructures to readily support growing economic development as humans have grown accustomed to or expect with anticipation in the future. And even if the world had the oil resources and infrastructures, the escalating waste and pollution are huge problems, which would make the planet dangerous for life, and eventually virtually uninhabitable.

\section{GEOPOLITICAL IMPLICATIONS AND CIVILIZA- TION CLASH}

Thwarted economic development due to escalating demand and the concomitant rising oil prices will have great geopolitical influences on the emerging world order. There does not appear to be any prompt remedy or ability to alleviate or stave off the possible imminent shortfall of oil and the dramatic economic and civilizational effects of this potential scarcity.

A new configuration of the world geopolitical scene may be about to appear in a world of civilization clash. Samuel Huntington $[32,6]$ proposes the idea of an emerging fragmented world. He argues that there is a likely intercultural and inter-religious conflict looming between future world powers, each superpower cohered from within through culture and religion. The new world order will be a multi-polar world. Huntington rejects the idea that the world will continue to acquiesce to Western homogenizing forces of globalization, which many critics suggest have been mounted to displace the interests of both Eastern and Islamic peoples. But we may be about to see these non-Western peoples aggressively pursue their vested interests from the vantage point of their newly emerging international power blocs.

So the gaping cleavages among humankind and the powerful sources of growing conflict will be cultural. The primary conflicts of future world politics will arise between groups of different united multinational civilizations. The clash of civilizations will be the future battle fronts.

For Huntington civilization can be defined as the broadest level of cultural identity of an individual, ethnic group or 
nation, or even group of nations. He highlights three major civilizations of influence:

\section{Christian Western}

Islamic-Arabic

\section{Chinese}

Based on the concept of civilization clash, the author's previous papers [33-35] foresee a looming new postAngloSaxon and post-globalization world which fragments along civilization fault lines. As Samuel Huntington puts it "the [historic] rivalry of the superpowers [will be] replaced by the clash of civilizations" [36].

This new international status quo will likely be made up of a tripartite mix of continent-wide civilization superpowers. A prelude to this newly forming world can be seen now with the Western AngloSaxon nations declining as rampant attempts for globalization have failed them. This Western AngloSaxon decline will make way for the anticipated newly formed continent-wide civilization superpowers which appear to be:

\section{Christian Europe}

Islamic PanArab nations with non-Arab Islamist Iran

An Asian conglomerate around the major nation states of Russia, China, Japan and India

In addition to the cohering phenomena of, for example, religion, ethnicity, historical legacy, and customs, Bosworth [37] comments that generally the different writing systems, as expressions of civilization, tend to compellingly support this 'tripartite' mix of regional globalization into civilization superpowers.

These superpowers will be unified in diversity; each will be welded together by overarching common faith systems and ethnicity, building on each member nation's inherent complementary strengths and weaknesses for internal synergies towards the economic and political vitality of the total superpower viability. Of course each superpower will have particular advantages and disadvantages in the new world order. However, each superpower will share common factors - they will have large to huge populations, supported by impressive economies, with significantly powerful militaries, including mass-destruction weapons with biochemical and nuclear capability. Each superpower will be a Titan.

For example, Christian Europe although short on natural resources and relying heavily on imports, has a history of technological development and efficient organization and administration, along with a highly educated population in democratic and relatively free capitalistic society. Europe can supply for export best quality machinery and products. Europe needs the continued supply of cheap oil to sustain its already high level of economic development.

Much of the world's remaining oil may be held in the Islamic Arab nations and Iran. Iran in its support of Islamist movements and trends already has significant influence in Iraq, Syria, Lebanon, Palestine and Egypt. Many other Islamic Arab nations fear the potential for Iran-backed political change or dissidence from their populations against the establishment. Several Islamic Arab nations (potentially to be Iran-backed Islamist) have large earnings from exporting their oil. However, these countries generally have physical and social infrastructures that do not put them in the moredeveloped-country category. And with the unrealized potential for balanced economic development in these countries, there will be a rising demand for their own oil from within as they further develop, somewhat reducing their oil export capacity.

The national constituents of the Asian superpower, except for Russia, are nations which have what may be called mystical eastern religions, in which the meditation process for enlightenment is common across the main Confucian and Indic religions. The four main Asian countries are Russia, China, Japan and India, and again except for Russia, they are not generally well endowed with energy resources and particularly oil. Combined, they have a huge total population, and the two most populous countries are China and India with massive populations. Also these two countries have not only cheap labour, but also significant pools of educated professionals to fire up their very impressive rate of economic development. Likewise, typical of Asia, several other Asian countries, with increasing adoption of technology in their industries, and cheap labour, can also compete on a world market with high value and low cost exports. Japan, with a highly industrialized developed economy, is a country with impressive education standards and technology in all fields, and Russia, with a superpower legacy of both education and technology, is resurgent. While impressive Asian economic development is beginning to take root and expand, there will be escalating high demand for energy resources in many nations across the continent.

Even though Russia on religious grounds may not seem to fit there, we must remember that Russia, as a huge Eurasian nation, has been largely rejected as an equal partner by the West [38], and as it does not fit with the Islamic states, it may have no choice but to reestablish friendly ties and deep cooperation, in economic, political and military matters with its Asian brothers.

The positioning of the three looming superpowers is interesting as they form a cluster around the Mediterranean and in Asia. This cluster configuration means that they either border each other or are in relatively close proximity, as shown in the following map of Fig. (6).

As we have seen the most abundant region for holding the remaining oil in the world is likely the Persian Gulf. These Persian Gulf countries (Abu Dhabi, Kuwait, Iraq and Saudi Arabia) are best positioned to be able to produce significant amounts of oil (before dwindling supplies set in) for on average the next 15 next years. Influence and good relations with this region for the other superpowers is vital for their continued supplies of oil.

Europe is largely resource deficient and the whole Former Soviet Union region, having reached peak oil production more than thirty years ago, is declining in production. The economies of three of the four major Asian nations - China, Japan and India (excluding Russia) - do not have across-theboard abundance of raw materials and this includes oil deficiency.

Eventually as the non-OPEC countries founder in oil production, OPEC will produce just about all the world's oil. This will give OPEC, a largely Islamic nations' cartel, great 


\section{Prospective Civilization Superpowers}

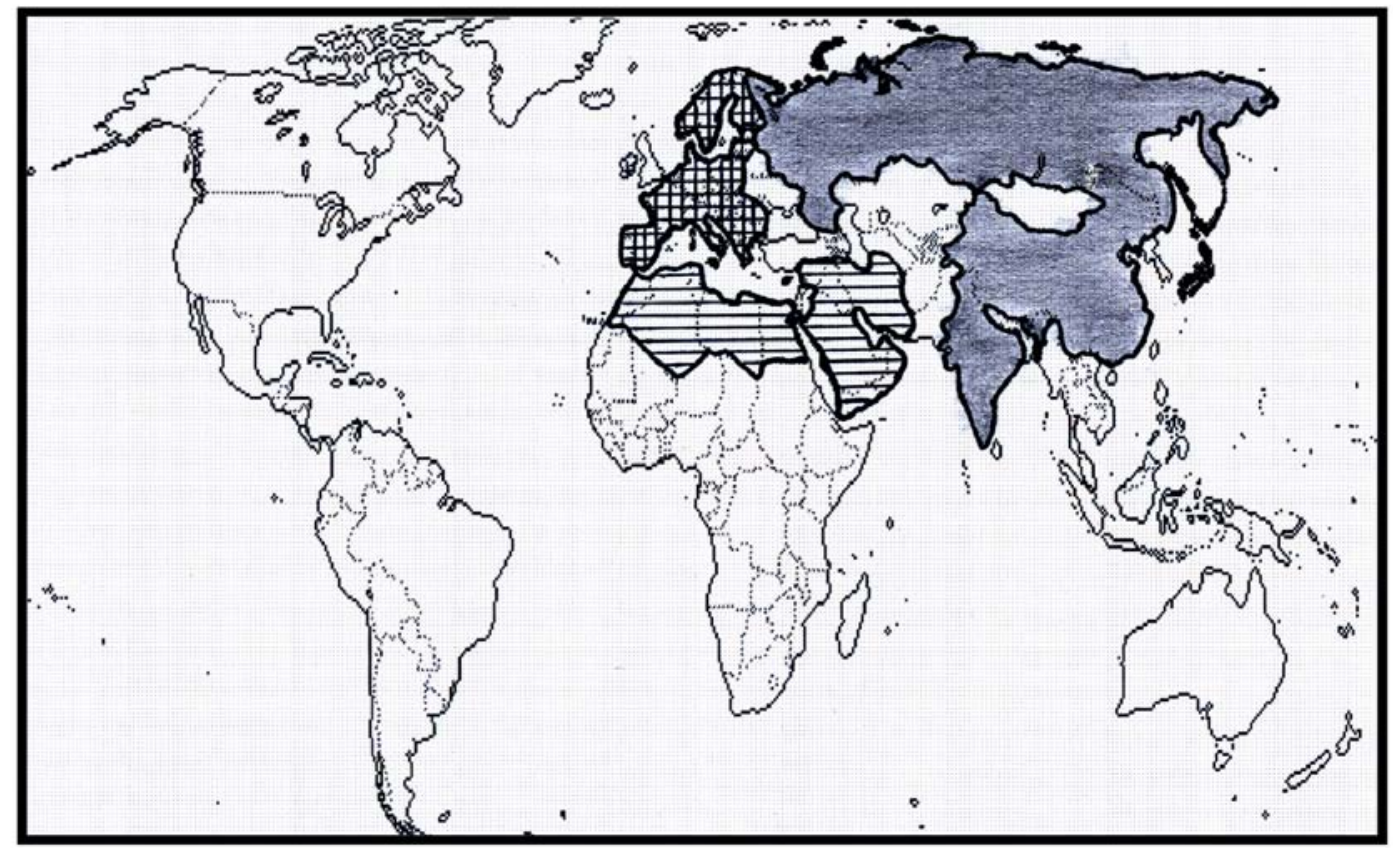

Fig. (6). Prospective world superpower regions.

civilizational power to wield its oil weapon for its own political agenda, at least for a couple of decades until their own oil levels seriously decline too.

It is important to note another point here, there is not enough readily available oil, at present in the world, to fuel universal economic development - maintaining the present economic development of the more developed Western nations, and at the same time promoting the economic development of the less developed countries is just not possible. One side of the economic divide will have to give way - that is for the West to suffer economic (and therefore civilizational) decline, or on the other side, the less developed countries will have to give up their push to economic development and the prospect of civilization greatness in newly formed civilization superpowers. And this will be a bitter pill that no civilization will succumb to and swallow easily.

In 2006 the OPEC states produced $42 \%$ of the world's oil [26], and with the majority of states around the world beyond peak oil, this proportion may be set to increase significantly in relatively oil-rich OPEC. El-Badri (2008) [16] comments that OPEC has $77 \%$ of the world's known reserves and this seems underpin OPEC with a more enduring oil supply than the rest of the world.

It does appear that the Islamic PanArab States, several of them making up most of OPEC, are much more embittered against the Christian West than they are against any other peoples. History and current world events would suggest that there could be a looming civilization clash between European Christendom and the Islamic world which would put the Asian superpower in an advantageous position for trade with the OPEC countries, even with preferential treatment including the discounting of oil supplies.

In this vein, the following quote from Salman [17] suggests that much of the future in developing relations with OPEC, may be outside the developed West (largely of Christendom) and towards the less developed, but high potential countries or blocs including Asia:

\begin{abstract}
Given that developing countries will be responsible for most energy demand growth in the future, and given oil's high energy concentration [in the Persian Gulf] and mobility, developing countries are the natural future partners of the big reserve holders [in the Gulf] on the producing side. The recent visit of the King of Saudi Arabia to China and India speaks for itself as an example of things to come in the dynamics and changes in the energy scene.
\end{abstract}

This has huge implications for access to reliable oil supplies at "favoured" prices. It may even be that eventually those states without good relations with the OPEC cartel, will not readily find reliable supplies of oil at any price, as OPEC uses oil as a devastating economic weapon, at least until their own supplies are critically low in another couple of decades. And as non-OPEC nations have rapidly falling oil supplies to export, OPEC is heading to be the world's primary supplier - that is of much more than half the worlds dwindling oil in the imminent few years ahead. 
In the face of world falling oil supplies, Paul Roberts [39] says, "We will face a post-oil future - a future that could be marked by recession and even war, as the ... big oil importers jockey for access to secure oil resources". And such conflict, considering the critical international context, could surely involve much of the world.

The predicted trend in the dominance of OPEC is shown in the graph of Fig. (7) below [7]. Specifically it was forecasted that the world oil production peak would be reached in 2006, and further predicts that around 2008 OPEC will begin to produce more oil than the rest of the world combined. Whenever this actually does happen, it will give these OPEC nations incredible "petropower". Also it is interesting to note that both sources of oil, OPEC and non-OPEC, are predicted to have falling production, although OPEC is better off in this trend.

\section{World, OPEC \& Non-OPEC Oil Production}

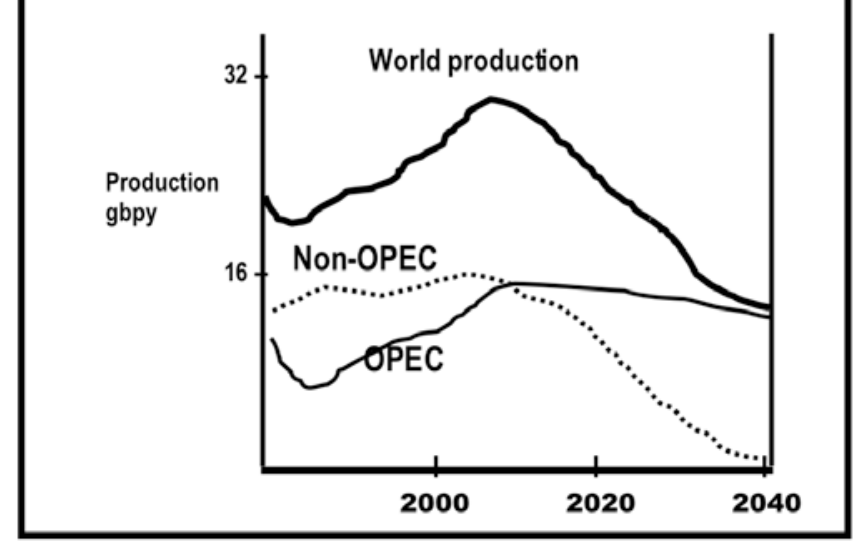

Fig. (7). World OPEC and Non-OPEC oil production [7].

\section{FUTURE SCENARIOS AND CONCLUSION}

Some may protest that conventional oil will not run out, or nonconventional oil will "save the day", and alternative sustainable energy technology will maintain universalization of economic development. And so the effects of Olduvai will be totally even proactively avoided. These theoretical possibilities, and some of their implications, have been considered as we moved through the paper. Most Americans would probably believe that the U.S. will be secure as a continuing world superpower in a new multipolar world. As Zakaria [40] argues, the looming world will be made up by "the rise of the rest", that is other nations around the world are rising, in addition to the current U.S. superpower. Conversely, Huntington [6] sees a fragmented world in civilization clash, and Kupchan [41] predicts conflict between the U.S.A. and Europe, even as America may decline [42].

Actually there are many possible scenarios for the geopolitical future of the world in the third millennium. However, in conclusion, the spotlight is on a possible new world era in a post-AngloSaxon and post-oil world, in civilization clash, while America suffers with critical economic malaise, and falls into decline, from eminent world power status.

So it may be that the U.S.A. in economic decline, is about to plunge from its position as the world's massive consumer that has helped keep the world afloat economically.
That rapid descent of the U.S.A. will not only have dramatic repercussions economically, by producing international financial uncertainty and chaos, as the world's biggest consumer disappears, but a rocky transition period will also leave the world without a great politically and militarily preeminent superpower. Just as nature hates a vacuum, so does the political realm, and so newly forming superpowers will surely vie for advantage and even supremacy in the newly forming world order.

Out of this universal mayhem with severe decline of some nations and the collapse of the international financial system, a newly world-dominant economic and political superpower may arise with its currency as the international convertible currency of choice.

This superpower and any other remaining viable superpowers or civilizations will need the reliable supply of oil, at the cheapest rate possible, and it appears OPEC will be the most likely supplier of significant quantities. It remains to be seen whether the two oil-hungry but oil-deficient civilization superpowers - Europe and the Asian conglomerate - can secure their supply of oil by the soft power of diplomacy, or whether the hard power of military force will be required as oil could be increasingly scarce against escalating demand.

For sure, these oil-hungry superpowers will go to great lengths to maintain oil supplies and so sustain economic development and the viability of their civilizations.

This imminent state of affairs may prove to be a testing ground for how the superpowers will compete for advantage, and how vociferous they can be for each to maintain, and even improve, its level of economic development, civilization greatness and world influence.

\section{REFERENCES}

[1] Trainer T. The death of the oil economy. Earth Isl J 1997. [cited Dieoff 2008 August 16]. Available from: http://dieoff.com/page 116.htm

[2] Robertson D. Oil chief warns of $\$ 200$ a barrel oil price. Times Online, 28 April, 2008: Available from: http://business.timesonline. co.uk/tol/business/industry_sectors/industrials/article3830383.ece

[3] Ferris-Lay C. Oil could reach $\$ 300$ says expert, ArabianBusiness.com, 28 February, 2008: Available from: http://www.arabian business.com/512436-oil-could-reach-us300-claims-expert

[4] The Hubbert Peak for World Oil, 2003: Available from: www. oilcrisis.com/summary.htm

[5] Duncan RC. The Olduvai Theory: Energy, population and industrial civilization, The Soc Contr, 2006: Available from: http://www. thesocialcontract.com/pdf/sixteen-two/xvi-2-93.pdf

[6] Huntington SP. The clash of civilizations and the remaking of world order. New York: Simon and Schuster 1996: 207-238.

[7] Duncan RC. The peak of world oil production and the road to the Olduvai Gorge. Geol Soc of Am, Summit. Reno, Nevada. May 13, 2000: Available from: http://dieoff.org/page224.htm

[8] Rempel H. Will the hydrocarbon era finish soon? [cited 2008 June 14]. Available from: http://www.hubbertpeak.com/Rempel/

[9] Anderson B. Peak oil primer andlLinks, Engy Bull, 24 February, 2008: Available from: http://www.energybulletin.net/primer.php

[10] Hanson J. Synopsis, 8 March, 2001. [cited 2008 June 2]. Available from: http://dieoff.org/synopsis.htm

[11] Bowman J. Empty holes and black swans, Ag Fncl, 12 February, 2008: Available from: http://www.agorafinancial.com/afrude/2008/ 02/12/empty-holes-and-black-swans/

[12] Zittel W, Schindler J. Crude oil the supply outlook, Energy Watch Group, October, 2007. [cited 2008 June 5]. Available from: http://www.energywatchgroup.org/fileadmin/global/pdf/EWG_Oilr eport_10-2007.pdf 
[13] EIA (Energy Information Association). Wld Cr Oil Prod, 19602007, 2008. [cited June 6]. Available from: www.eia.doe.gov/aer/ txt/ptb1105.html

[14] The Oil Drum. Peak Oil Update - August 2008: Production forecasts and EIA oil production numbers, 2008 September 13. [cited 2008 may 5]. Available from: http://www.theoildrum.com/node/ 3720

[15] Hoyos C. Saudis warn of oil capacity, Fncl Times, 22 April, 2008: Available from: http://www.ft.com/cms/s/0/db03994e-109f-11dd-b 8d6-0000779fd2ac,dwp_uuid=f2b40164-cfea-11dc-9309-0000779f d2ac.html?nclick_check=1

[16] El-Badri AS. The secretary general of OPEC, oil outlook and investment challenges, Nicosia chamber of commerce conference. Nicosia, Cyprus. January 16, 2008.

[17] Salman R. Skyrocketing energy prices - cause and implication, views from the Middle East, World energy council conference. Copenhagen, Denmark. February, 2006; 4: Available from: http:// www.wec.dk/arran/doc/rsa_280206.pdf

[18] Stanford S. What happens when..., The Oil Drum, 2005 December 7. [cited June 4 2008]. Available from: http://www.theoildrum. com/story/2005/12/7/461/35388

[19] Landers J. Nationalized oil staying in the ground, Dallas News, 17 July, 2007: Available from: http://www.dallasnews.com/sharedc ontent/dws/bus/columnists/jlanders/stories/071707dnbuslanders.40 43.html

[20] Aleklett K. The oil supply tsunami alert, Energy Bulletin, 25 April, 2005: Available from http://www.energybulletin.net/5655.html

[21] EIA (Energy Information Administration). World proved reserves of oil and natural gas, Most Recent Estimates, January, 2007: Available from: http://www.eia.doe.gov/emeu/international/reser ves.html

[22] Kerr RA, Service RF. What can replace cheap oil - and when? Sci, AAAS, July, 2005; 309(5731): 10. Available from: http://www.sci encemag.org/cgi/content/full/309/5731/101

[23] Taylor CL. The end of cheap oil. [cited 2008 September 29]. Available from: http://www.dcvelocity.com/articles/?article_id=16 98

[24] Tverberg GA. The disconnect between oil reserves and production, Engy Bull, 6 March, 2008: Available from: http://www.energybul letin.net/41311.html

[25] Cooke R. Oil fields are refilling naturally - sometimes rapidly, 2002. [cited 2008 June 10]. Available from: http://www.rense. com/general63/refil.htm

[26] BP (British Petroleum). Statistical review of world energy, June, 2007: Available from: http://www.bp.com/liveassets/bpinternet/glob albp/globalbp_uk_english/reports_and_publications/statistical_energ y_review_2007/STAGING/local_assets/downloads/pdf/statistical_re view_of_world_energy_full_report_2007.pdf
INEA. World energy outlook 2006, OECD/IEA, Paris, 2005. cited in Meneley D. Transition to Large Scale Nuclear Supply. [cited 2008 August 5]. Available from: http://www.inea.org.br/Meneley paper.htm

[28] USEIA (United States Energy Information Administration). World oil production, Future Demand Reference Case - International Outlook 2005.

[29] USEIA (United States Energy Information Administration). Future Supply: Projections by The Association for the Study of Peak Oil and Gas 2006

[30] Odum HT. Environmental accounting: Energy and environmental decision making, Canada: Wiley 1996, cited in Hanson J. Synopsis, 8 March, 2001; 817: 314. [cited 2008 June 3]. Available from: http://dieoff.org/synopsis.htm

[31] PeakEngineer, Eleven Incontrovertible Truths of Oil Production and Peak Oil Arguments, 2007 May, 23. [cited 2008 June 2]. Available from: http://www.peakoildesign.com/blog/peakengineer/ 11_incontrovertible_truths_oil_production_and_peak_oil_argumen ts

[32] Huntington SP. The clash of civilizations. For Aff 1993; 72(3): 22-49.

[33] Leigh J. Ever buoyant Roman Empire: Re-emerging Europe in post-globalization, Globalization, 2005, 5(1): Available from: http://globalization.icaap.org/content/v5.1/leigh.html

[34] Leigh J. Post-globalization Asian superpower in the making. World Aff 2006; 10(2): 14-34.

[35] Leigh J. The Persian lion and the crescent: Iran and the islamic world in the clash of civilizations. Wold Aff 2007; 11(1): 12-26.

[36] Bernstein R. A scholar's prophecy: Global cultural conflict, The NY Times, 29 September, 1997: Available from: http://query.ny times.com/gst/fullpage.html?res=9507EFDA1338F935A35752C1A 960958260

[37] Bosworth A. Globalization in the information age: Western, Chinese and Arabic writing systems, Globalization, 2004, 4(2): Available from: http://globalization.icaap.org/content/v4.2/bosworth.html

[38] Trenin D. Russia leaves the West. For Aff 2006; 85(4); Available from: http://www.foreignaffairs.org/20060701 faessay85407/dmitritrenin/russia-leaves-the-west.html

[39] Roberts P. Tapped out. Nat Geog June 2008; Available from: http://ngm.nationalgeographic.com/2008/06/world-oil/roberts-text

[40] Zakaria F. The rise of the rest. Nswk May 3, 2008; Available from: http://www.newsweek.com/id/135380/output/print

[41] Kupchan CA. The end of the West. The Atlantic Monthly November 2002: Available from: http://www.theatlantic.com/doc/prem/ 200211/kupchan

[42] Kolo G. The decline of American Empire. Counterpunch 17 December 2005: Available from: http://www.counterpunch.org/kolko 12172005.html 